2013, Vol. 2, Issue 2

\title{
PUBLIC SERVICE OBLIGATIONS IN THE AIR TRANSPORT SECTOR IN THE EUROPEAN UNION
}

\author{
Jakub Kociubiński
}

\section{Introduction}

The connectivity and accessibility of a given region translates directly into the European Union's (EU) objectives to foster territorial and social cohesion. In this vein, transport is a major facilitator of economic growth, having cross-sector impacts on numerous aspects of social and economic life $^{1}$. However due to various market failures some, mostly remote, regions are deprived of efficient transport connections with generally detrimental effects for them. Furthermore, for some areas (remote islands, mountain areas etc.) the only viable transport option is air travel. This makes the issue of connectivity more difficult, since air transport has high base costs and, in the case of remote islands, the level of demand does not normally justify the commencement of air operations. In other words, the State has to step up. The Public Service Obligation (PSO) is the regulatory solution to such concerns. This paper will provide an analysis of the legal basis and

* Jakub Kociubiński, PhD, University of Wrocław, Faculty of Law, Administration and Economics, Department of International and European Law.

1 K. Button, Wings Across Europe. Towards an Efficient European Air Transport System, Ashgate 2004, at p. 8 et seq. 
the mechanism of the EU's system of PSOs in the air transport sector, which leads to a clash between the antagonistic interests of competition versus cohesion-oriented goals.

\section{Regulatory framework of commercial aviation - historical background}

Ever since Regulation 141/61 entered into force in 1962, air transport has been effectively insulated from the competition rules of the EC Treaty ${ }^{2}$. This situation changed in 1986, when the Court of Justice of the European Union (CJEU) made clear in the Nouvelles Frontiéres case that, in the absence of a direct provision in Article 93 of the Treaty of Functioning of the European Union (TFEU), air transport remains outside the scope of the common transport policy and, therefore, the general rules of the Treaty (including the competition rules) apply to this sector $^{3}$. In the aftermath of this judgment, the European Commission pushed forward with the staged programme of liberalisation, known as the First Air Package ${ }^{4}$. The reform was possible mainly due to the

2 Council Regulation No. 141 exempting transport from the application of Council Regulation No. 17, O.J. 28.11.1962, L 124, p. 2751. The act excludes application of EEC: Regulation No. 17: First Regulation implementing Articles 85 and 86 of the Treaty (O. J. 21.2.1962, L 13, p. 204) to the air transport sector.

3 Criminal proceedings against Lucas Asjes and others, Andrew Gray and others, Andrew Gray and others, Jacques Maillot and others and Léo Ludwig and others (Nouvelles Frontières), Joined cases No. 209/84 to 213/84, Judgment of 30.4.1986, ECR 1986, p. 1425, at para 45 and 52. Treaty on the Functioning of the European Union, O.J. 30.3.2010, C 83, p. 47. All subsequent citations of the Treaty are taken from this source.

4 The First Air Package consisted of: Council Regulation (EEC) No. 3975/87 of 14.12.1987 laying down the procedure for the application of the rules on competition to undertakings in the air transport sector, O.J. 31.12.1987, L 374, p. 1; Council Regulation (EEC) No. 3976/87 of 14.12 .1987 on the application of Article 85 (3) of the Treaty to certain categories of agreements and concerted practices in the air transport sector, O.J. 31.12.1987, L 374, p. 9; Council Directive 87/601/EEC of 14.12 .1987 on fares for scheduled air services between Member States, O.J. 31.12.1987, L 374, p. 12 and Council Decision No. 87/602/EEC of 14.12.1987 on the sharing of passenger capacity between air carriers on scheduled air services between Member States and on access for air carriers to scheduled air-service routes between Member States, O.J. 31.12.1987, L 374, p. 19. As 
political impetus resulting from the formulation of the internal market programme for an upcoming Maastricht summit (1992) ${ }^{5}$. The second wave of liberalisation (Second Air Package) ${ }^{6}$ took place in 1990 and the third (Third Air Package) in 19927. With the adoption of the Third Air Package, the air transport market was fully liberalised as regards fares, passenger capacity and access to scheduled air services between Member States. From 1997, when all provisions of Third Air Package entered into force, all air routes within the EU have been fully open to competition for all so-called Community air carriers ${ }^{8}$. At the same time, the "escape clause"

regards the formulation of the internal market programme, see also European Parliament v. Council of the European Communities, Case No. 13/83, Judgment of 22.5.1985, ECR 1985, p. 1513.

5 B. Allan, M. Furse, B. Sufrin (eds), Butterworths Competition Law 3. Lexis Nexis 2008, at p. IX-73.

6 The Second Air Package consisted of: Council Regulation (EEC) No. 2342/90 of 24.7.1990 on fares for scheduled air services, O.J. 11.8.1990, L 217, p. 1; and Council Regulation (EEC) No. 2343/90 of 24.7.1990 on access for air carriers to scheduled intraCommunity air service routes and on the sharing of passenger capacity between air carriers on scheduled air services between Member States, O.J. 11.8.1990, L 217, p. 8.

7 The Third Air Package initially consisted of: Council Regulation (EEC) No. 2407/92 of 23.7.1992 on licensing of air carriers, O.J. 24.8.1992, L 240, p. 1; Council Regulation (EEC) No. 2408/92 of 23.7.1992 on access for Community air carriers to intra-Community air routes, O.J. 24.8.1992, L 240, p. 8; Council Regulation (EEC) No. 2409/92 of 23.7.1992 on fares and rates for air services, O.J. 24.8.1992, L 240, p. 15. The regulatory framework also consisted of following acts outside the packages: Commission Regulation (EEC) No. 2671/88 of 26.7.1988 on the application of Article 85 (3) of the Treaty to certain categories of agreements between undertakings, decisions of associations of undertakings and concerted practices concerning joint planning and coordination of capacity, sharing of revenue and consultations on tariffs on scheduled air services and slot allocation at airports, O.J. 30.8.1988, L 239, p. 9; Commission Regulation (EEC) No. $2672 / 88$ of 26.7 .1988 on the application of Article 85 (3) of the Treaty to certain categories of agreements between undertakings relating to computer reservation systems for air transport services, O.J. 30.8.1988, L 239, p. 13; Commission Regulation (EEC) No. $2673 / 88$ of 26.7 .1988 on the application of Article 85 (3) of the Treaty to certain categories of agreements between undertakings, decisions of associations of undertakings and concerted practices concerning ground handling services, O.J. 30.8.1988, L 239, p. 17. Other acts regulating inter alia ground handling, slots allocation are outside the scope of this paper. For details, see B. Allan, M. Furse, B. Sufrin (eds), supra note 5, at pp. IX-173 - IX-322.

8 The definition of a Community air carrier can be found in Article 2(8) of the Regulation (EC) No. 1008/2008 of the European Parliament and of the Council of 
encapsulated in Article 106(2) TFEU allows for a deviation from other Treaty rules for undertakings entrusted with the operation of Services of General Economic Interest (SGEI) ${ }^{9}$. In its ruling in the Ahmed Saeed case, the CJEU clearly stated that SGEIs can exist in the air transport sector ${ }^{10}$.

\section{Services of general economic interest in the acquis communautaire}

Services of General Economic Interest, to which Articles 14 and 106(2) TFEU and Article 36 of the Charter of Fundamental Rights refer, represent a sui generis category of services in $\mathrm{EU} \mathrm{Law}^{11}$. An analysis of Article 106(2) TFEU allows one to distinguish between two key elements of the SGEI definition: the general interest served by such services and an economic component ${ }^{12}$.

The concept of "General Interest" refers to services which Member States regard as vital to their societies and which they therefore subject to specific public service obligations ${ }^{13}$. In other words, public authorities guarantee their provision in the event of market failures ${ }^{14}$. The term "General Interest" can thus be equated with the term "Public Interest" and

24.9.2008 on common rules for the operation of air services in the Community (Recast) O.J. 31.10.2008, L 293, p. 3.

9 M. Szydło, Swobody rynku wewnętrznego a reguły konkurencji.Między konwergencja a dywergencja [Freedoms of Internal Market and Competition Rules. Between Convergence and Divergence], Wydawnictwo „Dom Organizatora”, Torun 2006, at p. 503-512.

10 Ahmed Saeed Flugreisen and Silver Line Reisebüro GmbH v. Zentrale zur Bekämpfung unlauteren Wettbewerbs e.V., Case No. 66/86, Judgment of 11.4.1989, ECR 1989, p. 803, at para 55.

11 Charter of Fundamental Rights, O.J. 30.3.2010, C 83, p. 399.

12 L.M. Soriano, How proportionate should anti-competitive state intervention be?, 'European Law Review', Vol. 28, No. 1, February 2003, p. 112, at p. 114.

13 See European Commission. Commission Staff Working Document, Guide to the application of the European Union rules on state aid, public procurement and the internal market to services of general economic interest, and in particular to social services of general interest, Brussels, 7.12.2010, SEC(2010) 1545 final.

14 Communication from the Commission - Services of general interest in Europe, Brussels 20.09.2000, COM(2000), O.J. 19.1.2001, C 17, p. 4 (See also earlier Commission Communications on services of general interest in Europe, O.J. 26.9.1996, C 281, p. 3); European Commission. Green Paper on Services of General Interest. 21.05.2003, $\operatorname{COM}(2003) 270$ final. 
its counterparts in various Member States (algemeen belang, intérêt public, interes publiczny etc. $)^{15}$. Despite obvious differences in the manner in which public services are organized in the various Member States, certain features are common to all national models ${ }^{16}$. All public services are provided under the supervision of State authorities which are equipped with special legal tools for intervention in the given sectors ${ }^{17}$.

It is worthwhile mentioning that the term "General Interest" has no direct equivalent in the national law of any Member States, which emphasises the independence of EU law and prevents the possibility of it being interpreted by reference to pre-existing national concepts ${ }^{18}$. At the same time, the Member States have a wide margin of discretion in defining which services them consider as being of general interest ${ }^{19}$. This freedom of definition is limited by the European Commission's supervision of manifest errors in such assessment ${ }^{20}$.

The second of the discussed elements - economic character - means that any entity engaged in operations of services of general interest must be categorized as an "undertaking" for the purposes of EU competition law ${ }^{21}$. The CJEU, since its ruling in the Höfner case, focuses on a functional

15 E. Malaret Garcia, Public Service, Public Services, Public Functions and Guarantees of Rights of Citizens: Unchanging needs in a Changed Context, [in:] M. Freedland, S. Sciarra (eds), 'Public Services and Citizenship in European Law. Public and Labour Law Perspectives', Oxford University Press, Oxford 1998, at p. 57.

16 Ibidem. See also M. Krajewski, U. Neergaard, J. Van de Gronden (eds), The Changing Legal Framework for Services of General Interest in Europe. Between Competition and Solidarity, T.M.C. Asser Press, Den Haag 2009, which provides overview of models of public services in various Member States.

17 Ibidem.

18 G. Hirsch, F. Montag and F-J Säcker (eds), Competition Law: European Community. Practice and Procedure. Article-by-Article Commentary, Sweet \& Maxwell, London 2007, at p. 1293.

19 Communication from the Commission - Services of general interest in Europe, supra note 14, at para 3.22. See also J. Kociubiński, Pojęcie usług świadczonych $w$ ogólnym interesie gospodarczym w prawie konkurencji UE [Notion of Services of General Economic Interest in EU Competition Law], 'Europejski Przegląd Sądowy', 8/2011, p. 8, at p. 9.

20 Ibidem. See also British United Provident Association Ltd (BUPA), BUPA Insurance Ltd and BUPA Ireland Ltd v. Commission of the European Communities, Case No. T-289/03, Judgment of 12.2.2005, ECR 2005, p. II-00741, at para 167.

21 A. Jones, B. Sufrin, EC Competition Law. Texts, Cases \& Materials, Oxford University Press, Oxford 2008, at p. 621. See also opinion of AG Stix-Hackl to Enirisorse SpA 
understanding of the concept of an undertaking ${ }^{22}$. According to this line of reasoning, the notion of an "undertaking" extends to every entity, regardless of its organizational form and the manner in which it is financed, engaged in an economic activity which constitutes offering goods and services on a given market ${ }^{23}$. The pursuit of profit is not

v. Ministero delle Finanze, Joined Cases No. C-34/01 and C-38/01, Opinion of 2.11.2002, ECR 2003, p. I-14243. Also Gesellschaft zur Verwertung von Leistungschutzerechten mbH (GVL) v. Commission of the European Communities, Case No. 7/82, Judgment of 2.3.1983, ECR 1983, p. 483.

22 See further W.J.P. Wils, The Undertaking as Subject of EC Competition Law and the Imputation of Infrigements to Natural or Legal Persons, 'European Law Review', Vol. 25, No. 2, April 2000, p. 99; P. Roth, V. Rose (eds), Bellamy \& Child, European Community Law of Competition, Sixth Edition, Oxford University Press, Oxford 2008, at pp. 92-93 \& 96-97 and G. Materna, Pojęcie przedsiębiorcy w polskim i europejskim prawie ochrony konkurencji [Notion of Undertaking in Polish and European Competition Law], Oficyna Wolters Kluwer Business, Warszawa 2009.

23 Klaus Höfner \& Fritz Elser v. Macrotron GmbH, Cases No. C-41/90, Judgment of 23.4.1991, ECR 1991, p. I-1979, at para 21. Also Dansk Pelsdyravelerforening v. Commission of the European Communities, Case No. T-61/89, Judgment of 2.7.1992, ECR 1992, p. II-1931, at para 50; Elliniki Radiophonia Tiléorassi AE (ERT) and Panellinia Omospondia Syllogon Prosspikou v. Dimotiki Etairia Pliroforissis (DEP) and Sotirios Kouvelas and Nicolaos Avdellas and others, Case No. C-260/89, Judgment of 18.6.1991, ECR 1991, p. I-2925, at para 31; Christian Poucet v. Assurances Générales de France and Caisse Mutuelle Régionale du Languedoc-Roussillon, Joined Cases No. C-159/91 and C-160/91, Judgment of 17.2.1993, ECR 1993, p. I-00637, at para 17; Consorzio Nazionale degli Spedizionieri Doganali (CNSD) v. Commission of the European Communities, Case No. T-513/93, Judgment of 30.3.2000, ECR 2000, p. II-1807, at para 36; Fédération Française des Sociétés d'Assurance (FFSA), Société Paternelle-Vie, Union des Assurances de Paris-Vie and Caisse d'Assurance et de Prévoyance Mutuelle des Agriculteurs v. Ministère de l'Agriculture et de la Pêche, Case No. C-244/94, Judgment of 16.11.1995, ECR 1995, p. I-04013, at para 14; Commission of the European Communities v. Italian Republic, Case No. C-35/96, Judgment of 18.6.1998, ECR 1998, p. I-3851, at para 36; Job Centre coop. arl. Case No. C-55/96, Judgment of 11.12.1997, ECR 1997, p. I-07119, at para 21; Albany International BV v. Stichting Bedrijfspensioenfonds Textielindustrie, Case No. C-67/96, Judgment of 21.9.1999, ECR 1999, p. I-5751, at para 77; Pavel Pavlov and others v. Stichting Pensioenfonds Medische Specialisten, Joined Cases No. C-180/98 to C-184/98, Judgment of 12.9.2000, ECR 2000, p. I-6451, at para 74, Aéroports de Paris v. Commission of the European Communities, Case No. T-128/98, Judgment of 12.12.2000, ECR 2000, p. II-3929, at para 107; J.C.J. Wouters, J.W. Savelbergh and Price Waterhouse Belastingadviseurs BV v. Algemene Raad van de Nederlandse Orde van Advocaten, intervener: Raad van de Balies van de Europese Gemeenschap, Case No. C-309/99, Judgment of 19.2.2002, ECR 2002, p. I-1577, at para 46; Federación Nacional de Empresas de Instrumentación Cientifica, Médica, Técnica y Dental 
essential, which is especially important in the case of public bodies, since their raison d'être is the pursuit of public interest goals ${ }^{24}$.

SGEI's may, therefore, be described as constituting an economic activity in the public interest ${ }^{25}$. The notion of "General Interest" is thus an umbrella category, including both economic and non-economic services ${ }^{26}$. The derogation in Article 106(2) TFEU can only be applied to the former ${ }^{27}$.

(FENIN) v. Commission of the European Communities, Case No. T-319/99, Judgment of 4.3.2003, ECR 2003, p. II-357, at para 35; Cisal di Battistello Venanzio \& C. Sas p. Instituto nazionale per l'assicurazione contro gli ifortuni sul lavoro (INAIL), Case No. C-218/00, Judgment of 22.1.2002, ECR 2002, p. I-691, at para 22; AOK Bundesverband and others v. Ichthyol-Gesellschaft Cordes, Hermani \& Co. and others, Joined Cases No. C-264/01, C-306/01, C-354/01 and C-355/01, Judgment of 16.3.2004, ECR 2004, p. I-2493, at para 46; Dansk Rørindustri A/S, Isoplus Fernwärmetechnik Vertriebsgesellschaft mbH and others, KE KELIT Kunstoffwerk GmbH, Brugg Rohrsysteme GmbH, LR af 1998 (Deutschland) $\mathrm{GmbH}$ and $\mathrm{ABB}$ Asea Brown Boveri Ltd b. Commission of the European Communities, Joined Cases No. C-189/02 P, C-202/02 P, C-205/02 P, and C-208/02 P, C-213/02 P, Judgment of 28.5.2005, ECR 2005, p. I-5425, at para 112; SELEX Sistemi Integrati SpA v. Commission of the European Communities, Case No. T-155/04, Judgment of 12.12.2006, ECR 2006, p. II-4797, at para 50 .

24 Commission Decision IV/31.734 - Film purchases by German television stations, O.J. 3.10.1989, L 284, p. 36. Whether an entity can be regarded as "undertaking" should be established on a case-by-case basis. See A. Svetlicinii, Back to the Basics: Concept of Undertaking and Economic Activity in SELEX Judgment, 'European Law Reporter', N. 12, December 2009, at p. 422. C. Bovis, Public Procurement, State Aid and Public Services: Between Symbiotic Correlation and Asymmetric Geometry, 'European State Aid Quarterly' 2003, Vol. 2, No. 4, at p. 558. Public authorities have discretion to define what constitutes interest. The issue of whether this definition is adequate in terms of fulfilling the needs of society is outside the scope of this paper, since it is of purely political character. It must be noted here that State organs, apart from possessing authority-related tasks, may be engaged in various economic activities just as any commercial operator. According to the principle of neutrality encapsulated in Article 345 TFEU undertakings, regardless of their ownership, follow exactly the same rules, so the issue whether or not an air carrier is a private or public company is irrelevant. See further M. Mataczyński, Artykut 345, [in:] A. Wróbel (ed.) Traktat o funkcjonowaniu Unii Europejskiej. Komentarz. Tom III [Treaty of Functioning of the European Union. Commentary], LEX Wolters Kluwer Business, Warszawa 2012, at p. 1072.

25 A. Jones, B. Sufrin, supra note 21, at p. 621.

26 U. Neergaard, Services of General Economic Interest: The Nature of the Beast, [in:] M. Krajewski, U. Neergaard, J. Van de Gronden (eds) supra note 16, at p. 21. See also Green Paper on Services of General Interest, supra note 14, at para 2.32.

27 A. Jones, B. Sufrin, supra note 21, at p. 621. 
Only an entity that constitutes an "undertaking" and is entrusted by public authorities with the operation of services in question can be the beneficiary of the aforementioned "escape clause" 28 . It is, therefore, possible that every community air carrier could potentially be an SGEI operator.

\section{Notion of Public Service Obligation}

Within the air transport sector, the concept of Services of General Economic Interest is closely linked with the notion of a Public Service Obligation. The CJEU has stated that carriers may be obliged by public authorities to operate on routes which are not commercially viable but which it is necessary to operate for reasons of general interest, which allows Article 106(2) TFEU to apply ${ }^{29}$. This approach has been implemented in Regulation 1008/2008, which provided the legal framework for the PSO concept, discussed here ${ }^{30}$.

In order for Article 106(2) TFEU to be applied, the relevant undertaking must be entrusted by an act of a public authority with the provision of given services ${ }^{31}$. The feature of entrustment requires that there is an act of obligation, such as authoritative act or a statutory regulation ${ }^{32}$. The entrusting organ must, therefore, have competences in

28 A. Grespan, Services of General Economic Interest, [in:] W. Mederer, N. Pesaresi, M. Van Hoof (eds), 'EU Competition Law. Volume IV. State Aid, Book Two', Claeys \& Casteels, Leuven 2008, at pp. 1133-1140. See the discussion J. Kociubiński, Ustugi świadczone w ogólnym interesie gospodarczym w prawie Unii Europejskiej. Wyzwanie dla europejskiego modelu gospodarczego [Services of general economic interest in European Union's law. Challenges for European economic model], Wydawnictwo „Dom Organizatora”, Torun 2013.

29 Ahmed Saeed, Case No. 66/86, supra note 10.

30 Article 16(1) of the Regulation 1008/2008 supra note 8.

31 AG Léger opinions in Wouters, Case No. C-309/99, supra note 23, at para 157-166 and Altmark Trans GmbH and Regierungspräsidium Magdeburg v. Nahverkehrgsesegesellschaft Altmark GmbH, and Oberbundesamwalt beim Bundesverwaltungsgericht, Case No. C-280/00, Opinion of 19.3.2002, ECR 2003, p. I-7747, at para 87. See also Empresa para Agroalimentação e Cereais SA v. Commission of the European Communities, Joined Cases No. T-204/97 and T-270/97, Judgment of 13.6.2002, ECR 2002, p. II-2267, at para 125-128 and cases quoted in the ruling.

32 G. Hirsch, F. Montag and F-J Säcker (eds), supra note 19, at p. 1294. 
the sphere of the relevant imperium ${ }^{33}$. Due to the existence of a variety of national structures of such norms, EU law is rather flexible in this respect; however the existence of a formal act is essential ${ }^{34}$. The scope of the SGEI in question must be clearly defined in this act ${ }^{35}$.

In its GVL ruling, the CJEU notes that mere authorisation by the State, despite its nature as an act of public authorities, is insufficient proof for the conclusion that there has been the necessary entrustment ${ }^{36}$. Similarly, a system of concessions for the provision of a given services could not constitute an entrustment ${ }^{37}$. Therefore, the absence of an act which unambiguously describes the nature of the relevant SGEI and confers legal responsibility for its provision to a named undertaking categorically excludes the applicability of Article 106(2) TFEU ${ }^{38}$.

Regulation $1008 / 2008$ provides that, to take into account the special characteristics and constraints of the outermost regions, in particular their remoteness, insularity and small size, and the need to properly link them with the central regions, Member States may impose a Public Service Obligation in respect of scheduled air services between an airport

33 Ibidem.

34 R. Lane, EC Competition Law, Pearson Education Limited, Harlow 2000, at p. 233; R. Whish, Competition Law. 4th Edition, Oxford University Press, Oxford 2001, at p. 232.

35 Community Framework for State aid in the form of public service compensation. Brussels 20.11.2007, SEC(2007) 1516, at para 5.4. The requirement of an act of entrustment cannot be seen as limiting the Member States' discretion in defining or adjusting SGEIs. See also the subsequent revision to the European Union framework for State aid in the form of public service compensation, O.J. 11.01.2012, C 8, p. 15. See D. Grespan, supra note 28, at p. 1137. See also Commission of the European Communities v. Kingdom of the Netherlands, Case No. C-157/94, Judgment of 23.10.1997, ECR 1997, p. I-5699, at para 40.

36 Gesellschaft zur Verwertung von Leistungsschutzrechten mbH (GVL) v. Commission of the European Communities, Case No. 7/82, Judgment of 2.3.1983, ECR 1983, p. 483, at para 29 and onward. See also decision that precedes judgment IV/29.839 - GVL, OJ 1981, L 370/49, at para 66.

37 Commission Decisions IV/37.717 - Uniform Eurocheques, O.J. 7.2.1985, L 35, p. 43 and IV/30.394 - Decca Navigator System, O.J. 15.2.1989, L 43, p. 27. See also Wasserund Abwasserzweckverband Gotha und Landkreisgemeinden (WAZV Gotha) v. Eurawasser Aufbereitungsund Entsorgungsgesellschaft $\mathrm{mbH}$, Case No. C-206/08, Judgment of 10.9.2009, ECR 2009, p. I-8377, at para 53, 55, 57, 59, 67-69, 77-80.

38 See Gerhard Züchner v. Bayeische Vereinsbank AG, Case No. C-172/80, Judgment of 14.7.1981, ECR 1981, p. 202. 
in the EU and an airport serving a peripheral or developing region within its territory, or on a thin route to any airport on its territory any such route considered as vital for the economic and social development of the region which the airport serves ${ }^{39}$.

The element of obligation is of the utmost importance ${ }^{40}$. Were this to be lacking, an SGEI operator may at any given moment cease to provide the services in question, whereas the very raison d'etre of the derogation encapsulated in Article 106(2) TFEU is to guarantee the constant and uninterrupted availability of the relevant SGEI ${ }^{41}$. Therefore, if an entrusted operator ceases to provide the services in question, this would constitute an infringement of the obligation and the undertaking could be held liable ${ }^{42}$.

\section{Scope of Public Service Obligation}

All PSO routes require the operating carrier to adhere to fixed levels of a service for the entire duration of the obligation. Mostly, the entrusted operator is required to ensure a minimum daily service frequency and/ or number of seats. There are often specific timetabling requirement with which the carrier must also comply. The determination of what such service requirements are is the sole responsibility of the entrusting authorities ${ }^{43}$.

39 Article 16 and recital 14 of the Regulation 1008/2008 supra note 8. List of all PSO routes can be found on European Commission website (list last updated on 25.2.2013): http://ec.europa.eu/transport/modes/air/internal_market/doc/pso_-_eu_and_eea_-_ feb_2013.pdf (29.08.2013).

40 Asociación Profesional de Empresas Navieras de Lìneas Regulares (Analir) and others $v$. Administración General del Estado, Case No. C-205/99, Judgment of 20.2.2001, ECR 2001, p. I-1271, at para 63-64.

41 Ibidem; W. Hoff, Europejskie obowiązi publiczne na przykładzie sektora elektroenergetycznego [Public Service Obligations on the Example of Electricity Sector], 'Studia Europejskie’, 4/2001, at p. 51; M. Szydło, supra note 9, at p. 506.

42 Fred Olsen v. Commission of the European Communities, Case No. T-17/02, Judgment of 15.6.2005, E.C.R 2005, p. II-02031, at para 189-190.

43 For details about country-specific requirements on various PSO routes see G. Williams, European Experience of Public Service Obligations, [in:] G. Williams, S. Bråthen (eds), 'Air Transport Provision in Remote Regions', Ashgate, Frnham 2010, at pp. 99-114. 
Given the liberalisation of the air transport sector, Member States are rather limited in their freedom to categorize certain air routes as being of general interest. Regulation 1008/2008 provides a set of criteria which must be used by the public authority when imposing a PSO on a given route. This enables an evaluation of whether or not the Member State has not abused the derogation from the treaty rules ${ }^{44}$. The evaluation of the necessity and adequacy of the PSO in question must take into account the proportionality between the envisaged obligation and the economic development needs of the region concerned, the possibility to have recourse to other modes of transport and the ability of such modes to meet the transport needs under consideration ${ }^{45}$. Air transport services have very high fixed operating costs, making it crucial to assess whether an alternative mode of transport, especially by rail, constitutes a viable alternative ${ }^{46}$.

Furthermore, Regulation 1008/2008 limits the PSO only to the extent necessary to ensure on that route the minimum provision of scheduled air services satisfying fixed standards of continuity, regularity, pricing or minimum capacity, which air carriers would not assume if they were solely considering their commercial interest ${ }^{47}$. It must be noted, however, that, in its Air Inter ruling, the CJEU stated that deviation from other Treaty rules via the derogation encapsulated in Article 106(2) TFEU is possible if they merely obstruct performance of the tasks in question, not only when such derogation is indispensable ${ }^{48}$.

44 M. Negnman, M. Jaspers, R. Wezenbeek, J. Stragier, Transport, [in:] J. Faull, A.Nikpay (eds), 'The EC Law of Competition', Oxford University Press, Oxford 2007, at p. 1580 and onwards.

45 Article 16(3) a \& b of the Regulation 1008/2008, supra note 8.

46 For further details see P.P. Belobaba, Airline Operating Costs and Measures of Productivity, [in:] P.P. Belobaba, A. Odoni, C. Barnhart (eds), 'The Global Airline Industry', Wiley, Chichester 2010, at pp. 113-153.

47 Article 16(1) of the Regulation 1008/2008 supra note 8.

48 Air Inter SA v. Commission of the European Communities, Case No. T-260/94, Judgment of 19.6.1997, ECR 1997, p. I-997, at para 138; Giuseppe Sacchi, Case No. 155/73, Judgment of 30.4.1974, ECR 1974, p. 409, at para 15. See also J. Kociubiński, Derogacja zasad konkurencji wobec przedsiębiorstw zobowiq̨zanych do świadczenia ustug $w$ ogólnym interesie gospodarczym a zasada proporcjonalnosici [Derogation of the Competition Rules to Undertakings Entrusted with the Operations of Services of General Economic Interest and the Principle of Proportionality], 'Studia Prawnicze' 2011, No. 2 (188) at p. 159. 


\section{Definition of the relevant market}

The decision to impose a PSO on an air route must be preceded by an analysis of whether there are viable alternative means of transports available which could fulfil the general interest goals in question. The rule of the thumb is that a State's intervention is allowed only in the event of market failure ${ }^{49}$. Definition of the relevant market serves as a benchmark allowing an assessment of whether or not the establishment of a PSO route is really necessary.

In order to define the relevant market, it is necessary to take into account both demand-side and supply-side substitutability ${ }^{50}$. In the view of the European Commission, demand-side substitutability represents "the most immediate and disciplinary force on the suppliers of a given [service], and therefore constitutes starting point in any analysis" 51 . This approach is consistent with the European Commission's reasoning that consumer interests should be the main focal point of any SGEI operations ${ }^{52}$. In the air transport sector, the European Commission considered that the relevant market would constitute any route between a given pair of cities $^{53}$. This so-called O\&D approach (point-of-origin/

49 J.L. Buendia Sierra, Article 86 - Exclusive Rights and Other Anti-competitive State Measures, [in:] J. Faull, A. Nikpay (eds), supra note 44, at pp. 598-701.

50 B. Allan, M. Furse, B. Sufrin (eds), supra note 5, at p. IX-248.

51 Commission Notice on the definition of the relevant market for the purposes of Community competition law, O.J. 9.12.1997, C 372, p. 5.

52 Communication from the Commission - Services of general interest in Europe, supra note 14, at para 2.8 \& 2.10. See also A. Héritier, Market integration and social cohesion: the politics of public services in European regulation, 'Journal of European Public Policy' 2001, Vol. 8, No. 5, p. 829; M. Ross, The Europeanization of Public Services Supervision: Harnessing Competition and Citizenship, 'Yearbook of European Law' 2004, Vol. 23, at p. 303; H-W. Micklitz, Universal Services: Nucleus for a Social European Private Law, [in:] M. Cremona (ed.), 'Market Integration and Public Services in the European Union', Oxford University Press, Oxford 2011, at p. 73.

53 Commission Decisions M.3280 - Air France/KLM, O.J. 9.3.2004, C 60, p. 5; 2004/841/EC, Air France/Alitalia (COMP/A.38284/D2), O.J. 9.12.2004, L 362, p. 17; easy Jet Airline Company v. Commission of the European Communities, Case No. T-300/04 (removed from the registry, O. J. 20.10.2007, C 247, p. 41). 
point-of-destination) has been upheld by the $\mathrm{CJEU}^{54}$. During the analysis, it is also important to take into account the profile of passengers travelling on a give route. Two main categories could be distinguished: Time-sensitive passengers focus mainly on flexibility ${ }^{55}$. The primary criteria according to which they select an airline are the number of daily flights, the location of the airport, the convenience of departure and arrival times and the opportunity to reschedule their reservation at short notice ${ }^{56}$. The non-time-sensitive passengers are, in general, more price-oriented ${ }^{57}$. They require less flexibility and are willing to accept longer journey time ${ }^{58}$. This classification largely coincides with the distinction between business and leisure travellers ${ }^{59}$.

Taking into account the high operating costs within the airline industry, it is also important to ensure that there are no alternative, cheaper modes of transport available for a given route ${ }^{60}$. Especially on short-haul routes, road or rail transport may substitute air travel ${ }^{61}$. It is also necessary to establish whether low-cost carriers and, in certain situations, charter operators provide services on the route in question ${ }^{62}$. Last, but not least, it should be take into consideration whether or not

54 B. van Houtte, Relevant Markets in Air Transport, 'Common Market Law Review' 1990, Vol. 27, No. 3, at p. 527.

55 Commission Decision Air France/Alitalia, supra note 53, at para 11.

56 Ibidem.

57 Commission Decisions Case JV.19 - KLM/Alitalia, O.J. 1999, C 184, at. para 21; COMP.D.2.37.444 - SAS Maersk O.J. 5.10.2001, L 265, p. 15, at para 30; Air Francel Alitalia, supra note 52, at para 41, 44-46; Case M.2041 - United Airlines/US Airways O.J. 2001, C 270, p. 131, at para 18.

58 Commission Decision Air France/Alitalia, supra note 53, at para 11.

59 J. Kociubiński, Relevant Market in Commercial Aviation of the European Union, 'Wroclaw Review of Law, Administration \& Economics' 2011, Vol. 1, No. 1, Issue 1, at p. 12.

60 Ibidem; T. Soames, EC Competition Law and Aviation: "caution optimism spreading its wings”, 'European Competition Law Review’ 2006, Vol. 27, at p. 599.

61 Ibidem.

62 For example, the Commission concluded that the rail link from Brussels to London operated by the high-speed trains of the Eurostar line constitutes a viable alternative to the scheduled air service. Generally, for time-sensitive passengers, alternative means of transport may be possible only where travel time is not significantly increased. However, for price-minded travellers, travel time might be less important, making this option more attractive for them. 
a similar service is provided from other airports in the vicinity of the analysed location ${ }^{63}$. The so-called airport catchment area (which is the distance that passengers are willing to travel to get to a given airport) will vary depending on the length of the route and the profile of passengers, so it is important to factor that in ${ }^{64}$. All such elements must be taken into consideration during the process of defining the relevant market but, at the end of a day, it is obvious that both categories of passengers have different needs and a service tailor-made for one of them does not necessarily fulfil the needs of the other ${ }^{65}$. Therefore, the final evaluation done by the public authorities must strike a happy medium between these conflicting interests.

\section{Selection of a SGEI operator}

In its 2003 Green Paper on Services of General Interest, the European Commission expressed the view that the European Union respects such diversity and the roles of national, regional and local authorities in ensuring the well-being of their citizens and in guaranteeing democratic choices regarding, inter alia, the level of service quality. This diversity explains the various degrees of EU action and the use of different instruments ${ }^{66}$. This line of reasoning is further augmented by the Protocol on Services of General Interest which emphasizes "the essential role and the wide discretion of national, regional and local authorities in providing, commissioning and organizing services of general economic interest as closely as possible to the needs of the users" 67 .

Equally, one must not lose sight of the fact that SGEI operators are undertakings and thus are subject to EU competition law ${ }^{68}$. This also means that, when public authorities decide to entrust a particular SGEI mission to a third party (undertaking), this operator should (with some

63 J. Kociubiński, supra note 59, at pp. 18-19.

64 M. Negnman, M. Jaspers, R. Wezenbeek, J. Stragier, supra note 44, at p. 1580.

65 Ibidem.

66 Green paper on Services of General Interest, supra note 14, at para 10 \& 11.

67 Protocol on Services of General Interest, O.J. 30.3.2010, C 306, p. 158.

68 A. Gleiss, M. Hirsh, Kommentar zum EG-Kartellrecht, Band 1 (Art. 81 [=85] und Gruppenfreistellungsverordungen), Verlag Recht und Wirthschaft 1993, at p. RN 297. 
exceptions) be selected according to the rules prescribed in European public procurement law ${ }^{69}$. In this context, public procurement serves as a link between the undertaking and an organ of public authority, which allows for the creation of a legal bond of entrustment and thus enables Article 106(2) TFEU to come into play ${ }^{70}$.

At the level of primary legislation, there are no provisions explicitly dedicated to public procurement ${ }^{71}$. However, this is closely linked with the general principles of EU law, especially with the principles of nondiscrimination, transparency, proportionality and the fundamental freedoms of the internal market ${ }^{72}$. Such principles provide the direction for the adoption and interpretation of secondary legislation regarding public procurement within the $\mathrm{EU}^{73}$.

69 See inter alia Frequently Asked Questions concerning the application of public procurement rules to social services of general interest. Brussels 20.11.2007, SEC (2007) 1514. The Commission expressed the view that, if public authorities are engaged in the provision of "social services of general interest", competition law should not be applied. If, however, they are entrusting third party (i.e. undertakings) with discharging services of general interest (whether social or not), they are bound by public procurement rules, since the operation has a distinct economic character. The legal basis for entrustment of a SGEI mission is Directive 2004/18/EC of the European Parliament and of the Council of $31^{\text {st }}$ March 2004 on the coordination of procedures for the award of public works contracts, public supply contracts and public service contracts, O.J. 30.4.2004, L 134, p. 114.

70 C. Bovis, Financing Services of General Economic Interest in the EU: How do Public Procurement and State Aids Interact to Demarcate between Market Forces and Protection, 'European Law Journal', Vol. 11, No. 1, January 2005, at p. 92.

${ }^{71}$ C.H. Bovis, EU Public Procurement Law: Case Law and Regulation, Edward Elgar Publishing, Cheltenham, Northampton MA 2007, at pp. 17-63.

72 A. Sołtysińska, Zamówienia publiczne w Unii Europejskiej [Public Procurement in European Union], Kantor Wydawniczy Zakamycze, Kraków 2004; A. Borkowski, M. Guziński, K. Horubski, K. Kiczka, L. Kieres, T. Kocowski, W. Miemiec, M. Szydło, 'Prawo zamówień publicznych' [Law of Public Procurement], Kolonia Limited, Wrocław 2008.

${ }^{73}$ Commission of the European Communities v. Kingdom of Spain, Case No. C-71/92, Judgment of 17.11.1993, ECR 1993, p. I-5923; Hospital Ingenieure Krankenhaustechnik Planungs-Gesellschaft mbH (HI) v. Stadt Wien, Case No. C-92/00, Judgment of 18.6.2002, ECR 2002, p. I-5553, at para 42. See also SA Transporoute et travaux v. Ministerie de travaux publics (Transporoute), Case No. 76/81, Judgment of 10.2.1982, ECR 1982, p. 417; Commission of the European Communities v. Republic of Ireland (IIRS), Case No. 45/87, Judgment of 22.9.1988, ECR 1988, p. 4929; Commission of the European Communities v. Republic of Italy, Case No. C-3/88, Judgment of 5.12.1989, ECR 1989, p. 4035; Du Pont de Nemours Italiana SpA v. Unità sanitaria locale $N^{o} 2$ di Carrara, Case No. C-21/88, 
The provisions of Regulation 1008/2008 regarding the selection of a PSO route operator are lex specialis to generic public procurement rules, whilst remaining consistent with the aforementioned general principles. The procedure has the form of a public tender and is open for any carriers within the $\mathrm{EU}^{74}$. However, tender procedures have been viewed by certain carriers as an impending factor to their tendering for a route. In the event of failing to win a tender round, an airline may be faced with significant sunk costs. Accordingly, is unsurprising that most PSO operators are locally-based carriers ${ }^{75}$. It must be noted that Regulation 1008/2008 does not provide any timeframe for the duration of a PSO. It is submitted, however, that Member States may limit access to scheduled air services on a particular route to only one Community air carrier for a period of up to five years, following which the situation shall be reviewed ${ }^{76}$. Nevertheless, this does not automatically mean that a PSO is intended to be limited to the same length of time. The establishment of a fixed time limit for a PSO seems to be justifiable, since undertakings operating in a competition-free environment with public funding tend to lose their effectiveness over time ${ }^{77}$.

\section{Financing of a Public Service Obligation}

Since PSOs are to be imposed on routes where carriers, under normal economic conditions, would not undertake their operations, public

Judgment of 20.3.1990, ECR 1990, p. I-889; Commission of the European Communities v. Kingdom of Denmark (Storebaelt), Case No. C-243/89, Judgment of 22.6.1993, ECR 1993, p. I-3353.

74 Article 17 of the Regulation 1008/2008, supra note 8.

75 B. O’Fee, Tendering and Operating PSO Routes [in:] G. Williams, S. Bråthen (eds), supra note 43 , at p.106.

76 Article 16(9) of the Regulation 1008/2008 supra note 8. See also; G. Anger, J. Holmér, P-E. Westin, Experience of PSO and Tendering Process in Sweden, in: G. Williams, S. Bråthen (eds), supra note 43, at pp. 115-164.

77 See A. Sullivan, S.M. Sheffrin, Economics: Principle in Action, Pearson/Prentice Hall 2007. On economic benchmarks of effectiveness see further R.O. Zerbe Jr., Economic Efficiency in Law and Economics, Edward Elgar Publishing, Cheltenham 2001. 
authorities have to compensate an incumbent operator for any losses generated by services on a PSO route ${ }^{78}$. Competing views regarding the legal classification of public funds for SGEI operators have become known, respectively, as the 'compensation approach', pursuant to which such measures are not regarded as State aid provided that they do not exceed the appropriate remuneration for the costs of the service in question and the 'State aid approach' whereby such measures should be deemed to constitute State aid ${ }^{79}$. The groundbreaking Altmark case offered the opportunity to conciliate the different approaches. The CJEU set out four conditions, all of which must be satisfied in order for the measure not to constitute State aid but, rather, to fall within the derogation encapsulated in Article 106(2) TFEU ${ }^{80}$.

Regulation 1008/2008 reads as follows:

The Member State concerned may compensate [PSO operator], for adhering to the standards required by a public service obligation imposed (...). Such compensation may not exceed the amount required to cover the net costs incurred in discharging each public service obligation, taking account of revenue relating thereto kept by the air carrier and a reasonable profit.

78 See inter alia G. Williams, European Experience with Direct Subsidization of Air Services, 'Public Money \& Services' 2005, Vol. 25, No. 3, at p. 151; G. Williams, R. Pagliari, A Comparative Analysis of the Application and Use of Public Service Obligations within the EU, 'Transport Policy', 11/2004, at p. 55.

79 K. Bacon (ed.), 'European Community Law of State Aid', Oxford University Press, Oxford 2009, at para 2.63.

80 Altmark, Case C-280/00, supra note 31. These are: the undertaking must have a clearly defined public service obligation to discharge (para 89 and also and BUPA, Case No. T-289/03, supra note 20, at para 181); the parameters of the basis on which compensation is calculated must be established in advance in a objective and transparent manner, to avoid overcompensation which may confer economic advantage to the recipient operator (para 90); compensation cannot exceed what is necessary to cover all costs incurred in the discharge the SGEI in question, taking into account the relevant receipts and a reasonable profit for the operator (para 92); where the undertaking which is to discharge public service obligation is not chosen pursuant to a tendering procedure the level of compensation needed must be determined on the basis of analysis of the costs which 'a typical, well run undertaking' would have incurred in discharging those obligations (para 93). 
This provision must be interpreted in the light of the principles formulated in the Altmark judgement (and subsequent legislation) ${ }^{81}$.

The first logical step when assessing the proportionality of compensation is to identify the costs attributable to operations on a given PSO route. While this question is relatively straightforward when the undertaking only provides SGEI (enabling all of its costs to be taken into account), it becomes increasingly complicated when the incumbent undertaking also carries out non-SGEI activities ${ }^{82}$.

Whereas, in its BUPA judgment, the General Court recognized a wide discretion for Member States to define the methodology for determining additional costs incurred in discharging an SGEI mission, in the aftermath of the Altmark judgment the European Commission adopted regulatory packages (the so-called Altmark Package I and II) which provide a basic framework for public service compensation assessments ${ }^{83}$. These packages point to a full-costs allocation methodology, which means the calculation should also factor in all variable costs incurred in providing a given SGEI, an appropriate contribution of fixed costs common to the SGEI and other activities, and an adequate return of the undertaking's own capital assigned to the service in question ${ }^{84}$. Such costs shall be calculated on the basis of generally accepted cost-accounting principles ${ }^{85}$. These

81 Article 17(8) of the Regulation 1008/2008, supra note 8. Some of Altmark criteria will thus be automatically satisfied ie. the need for a tender.

82 A. Grespan, supra note 28, at p. 1161.

83 BUPA, Case No. T-289/03, supra note 19, at para 214 \& 220; FFSA, Case No. T-106/95, supra note 23, at para 105 and Fred Olsen, Case No. T-17/02, supra note 41, at para 266. The so-called Altmark Package II consisted of the following acts: Communication from the Commission on the application of the European Union State aid rules to compensation granted for the provision of services of general economic interest, O.J. 11.01.2012, C 8, p. 4; Commission Decision of 20.12.2012 on the application of Article 106(2) of the Treaty on the Functioning of the European Union to State aid in the form of public service compensation granted to certain undertakings entrusted with the operation of services of general economic interest, O.J. 11.01.2012, L 7, p. 3 and European Union Framework, supra note 35.

84 See details: E. Righini (ed.), New EU State Aid Rules for Services of General Economic Interest, 'European State Aid Quartery - Special Issue 2012'.

85 Ibidem. 
principles are complemented by the Transparency Directive ${ }^{86}$, which creates the obligation to maintain separate accounts for activities of general interest and these outside the PSO. Therefore, the entrusted undertaking must be capable of showing separately the costs and receipts associated with a given SGEI and those of other services. The raison d'etre of the Transparency Directive is to provide a lex generalis to be applied without prejudice to more specific provisions of EU law, in order to ensure the effective allocation of public funds ${ }^{87}$.

Both the Altmark Packages and Regulation 1008/2008 explicitly allow PSO operators to make a "reasonable profit" from providing the SGEI in question ${ }^{88}$. A reasonable profit means a rate of return on the undertaking's own capital necessary for providing the SGEI in question, which takes account of the existence (or absence) any associated risks. This rate shall not exceed the average rate of return present within the sector in recent years ${ }^{89}$. Member States are allowed to introduce incentive criteria concerning, in particular, the quality of a given SGEI.

Since the level of compensation should not exceed what is necessary for a given PSO service, plus a reasonable profit, any excessive or misused compensation will amount to Staid aid and must be returned, as per Article 108 (3) TFEU. For the sake of flexibility, SGEI operators are allowed to carry forward any over-compensation, provided that this does not exceed $10 \%$ of annual compensation ${ }^{90}$. This situation should be reviewed

86 Commission Directive 2006/111/EC of 16.11.2006 on the transparency of financial relations between Member States and public undertakings as well as on financial transparency within certain undertakings, O.J. 17.11.2006, L 318, p. 17.

87 D. Grespan, supra note 28, at p. 1166.

88 This only reaffirms the position already adopted by the Commission. See inter alia decision C88/1997 - Crédit Mutuel (First Crédit Mutuel Decision), O.J. 31.7.1997, C 205, p. 5.

89 See this line of reasoning in the European Commission Press Release 22.10.2008, State aid: Commission endorses remuneration for distribution of postal bonds by "Poste Italiane", IP/08/1564 \& 22.11.2006, State aid: Poste Italiane - Commission endorses remuneration for distribution of postal savings books; opens investigationinto distribution of postal bonds, IP/06/1605.

90 L. Coppi, SGEI Compensation in the Almunia Package - An Economic View, [in:] E. Righini (ed.), supra note 84, at p. 44. 
at intervals, which should not exceed four years ${ }^{91}$. All overcompensation accounted at the end of that period should be repaid.

\section{Concluding remarks}

Connecting remote regions with the remainder of a State is certainly a justified aim, in terms of fulfilling the needs of society but, embracing a larger view, one must query the impact of PSOs on the overall competitiveness of the airline industry. Critics have suggested that some of the largest PSO routes could be self-sustaining and that the subsidization thereof is merely a waste of public funds. Recourse to subsidies or restricting access to a given route is, therefore, purely a political issue. In this context, the system of PSO organization seems to be somewhat flawed. In an important omission from the PSO system, the European Commission publishes calls for tender in the Official Journal, but lacks the power to refuse State nominations of particular routes.

This stems from the very essence of the SGEI, which allows Member States a wide discretion to define and adjust the services in question. Each aspect of supervision is both ex post in character and extends only to manifest errors of assessment. Additional, albeit merely circumstantial, evidence of the deficiency of the PSO system can be found in the fact that the vast majority of incumbent operators are local, regional airlines. Financial backing from public authorities, in the guise of public service compensation, keeps such carriers afloat. Therefore, without any stretch of the imagination, the political importance of PSO subsidies is self-evident.

In times of austerity, greater emphasis should be placed on the financial adequacy of public service compensation. It should not be forgotten that the services in question are funded from the public purse. Scrapping the subsidizing of self-sustained routes and preventing incumbent airlines from allocating a disproportionate amount of their costs to the subsidised operation in order to raise the level of financial backing could, to some degree, be achieved by increasing transparency

91 See inter alia Commission Decision, State Aid E 14/2005 - Portugal (General financing system for RTP) (ex NN 133/A/2001, NN 85/A/2001 i NN 94/A/1999) [nyr], at para 103. 
regarding the level of subsidies (something which the Transparency Directive can only partially solve). With Member States having the final say as to which routes to designate for subsidies, the problem of subsidisation of self-sustaining routes would not be adequately ameliorated, but closer ex lege scrutiny using all means possible should be introduced to the existing supervisory mechanisms. In conclusion, whilst the raison d'étre of a common legal framework for organisation and financing PSO routes is by all means a step in the right direction, at this stage the currently binding legal provisions remain somewhat flawed. 